\title{
"LAWS THAT MAKE THEM SLAVES THERE, MAKE THEM SLAVES HERE": \\ THE STATUS OF SLAVERY IN ENGLAND AND ITS INFLUENCE ON THE COLONY OF NOVA SCOTIA
}

\section{NAYTHAN POULIN}

Caleb Jones, a Maryland slaveholder and British sympathizer, decided to immigrate to Nova Scotia in order to maintain his claims to property following the American Revolution. In the summer of 1786, five of Jones' slaves escaped, among them a twenty-four-year-old woman Nancy and her son Lidge. Although Jones captured Nancy and Lidge in the summer of 1786, Lidge would eventually attempt another escape thirty years later. Effectively, Lidge represented the uncertainties of slavery in the transatlantic world following the American Revolution. Lidge had been forced to migrate as a slave from Maryland to Nova Scotia, experienced a brief moment of freedom, was re-enslaved for thirty years, and then freed, perhaps permanently. ${ }^{1}$ Nova Scotia was the only colony in the transatlantic world to possess no statute laws or slave codes; thus, Nova Scotia did not have legal authorization to enforce slavery. The absence of statute law in Nova Scotia engendered significant legal ambiguities on the general status of slavery and enslaved people in the colony. Following 1783, Nova Scotia's legislative and judicial institutions were greatly destabilized by Loyalist migration, and the colony searched across the transatlantic world for legal answers. England, similarly to Nova Scotia, did not possess any statute laws to enforce slavery; the metropole and the colony of Nova Scotia thus shared a similar ambiguity towards the status and regulation of slavery. This paper argues that judicial rulings made in Nova Scotia regarding the status of slavery were directly influenced by

\footnotetext{
${ }^{1}$ Harvey A. Whitefield, North to Bondage: Loyalist Slavery in the Maritimes (Vancouver: UBC Press, 2016), 3-4.
} 
common law established in England. Specifically, this paper analyzes Somerset v Stewart and subsequent cases in England to determine the influence of case law on Nova Scotia's Supreme Court and evaluate its success in eradicating slavery. Ultimately, slavery in the Canadian colonies is a topic that has been erased from the historical narrative and has been ignored by generations of historians. ${ }^{2}$ Nonetheless, it signifies that more work is required to establish stronger connections between the metropole and Canadian colonies, but also the intercolonial influences on slavery.

In 1769, Charles Stewart, accompanied by his slave James Somerset traveled from Boston to England in order to conduct business. In 1771, Somerset decided to run away from his master but was later captured and imprisoned with the intent of being sold abroad. By the support of affidavits, Lord Mansfield then ordered a writ of habeas corpus for the unlawful imprisonment of the enslaved man, and Somerset was presented before his lordship. On June $22^{\text {nd }} 1772$, Mansfield ruled that, "I cannot say that this case is allowed or approved by the law of England; and therefore, the black must be discharged." ${ }^{3}$ The impact of Somerset on the abolition of slavery in England is debatable. Some historians argue that Somerset effectively ended slavery in 1772, while others debate that slavery ended in England during the emancipation of 1834.

Historian William R. Cotter states that, while there is no denying that Somerset won his case and was discharged, what is unclear is the scope behind Mansfield's ruling. ${ }^{4}$ Legal scholar William M. Wiecek argues that Somerset only solved two problems related to master and enslaved

\footnotetext{
${ }^{2}$ Whitefield, 4-5.

3 "Somerset v Stewart (1772)," in Judicial Cases Concerning American Slavery and the Negro, ed. Helen Catterall (Washington D.C.: Carnegie Institute, 1926), 14-15.

${ }^{4}$ William R. Cotter, "The Somerset Case and the Abolition of Slavery in England," History 79, no. 255, (1994): 3334.
} 
relations in England; a master could not remove a slave from England against his will, and a slave could gain access to writ of habeas corpus if threatened with removal. ${ }^{5}$

There is evidence to support that Mansfield was ruling on a case concerning habeas corpus, and not about slavery. Mansfield`s ruling on Somerset suggests that "On a return to habeas corpus; the only question before us is, whether the cause on the return is sufficient? If it is, the negro must be remanded; if it is not, he must be discharged." ${ }^{\prime 6}$ It is clear that Mansfield chooses his words carefully by explicitly stating that the "only question" regarding his ruling in Somerset is set on the principles of whether or not Somerset was lawfully detained. Furthermore, Mansfield acknowledges the master and slave relationship, "that the slave departed and refused to serve,"7 yet does not comment on whether or not such a relationship is legal in England. The problem with master and slave relations in England was that there was trouble distinguishing between a "slave" and "servant," making slavery a complex legal landscape for judges. ${ }^{8}$

Enslaved people who entered England were not free, yet the English environment gave slaves new tasks that increased their personal freedom. James Somerset, for instance, was permitted to travel long distances between London and the English countryside to relay messages on behalf of his master. Rabin argues that Somerset`s freedom to travel may have caused some ambiguity, in that he was free to travel but not free. ${ }^{9}$ Due to the ambiguity of the status of slavery in England, Mansfield attempted to avoid slavery and sought to satisfy neither pro- nor anti-slavery advocates. $^{10}$

\footnotetext{
${ }^{5}$ William M. Wiecek, "Somerset: Lord Mansfield and the Legitimacy of Slavery in the Anglo-American World," The University of Chicago Law Review 42, no. 1 (1974): 87.

6 "Somerset v Stewart (1772)," 14-15.

7 "Somerset v Stewart (1772)," 14-15.

${ }^{8}$ Dana Rabin, “'In a Country of Liberty?': Slavery, Villeinage and the Making of Whiteness in the Somerset Case (1772)," History Workshop Journal 72, (2011): 10.

${ }^{9}$ Rabin, 10.

${ }^{10}$ Rabin, 14.
} 
Perhaps the confusion regarding Mansfield's ruling on habeas corpus and the freedom of enslaved people in England is closely related to Lord Henley's proclamation ten years prior. In Shanley v. Harvey (1762), Lord Henley expressed his legal opinion that, "As soon as a man sets foot on English ground he is free: a Negro may maintain an action against his master for ill usage, and may have a Habeas Corpus if restrained of his liberties." ${ }^{11}$ Lord Henley's opinion was directly related to a case concerning habeas corpus and explicitly stated that England offered de-facto freedom to slaves, yet it was not part of an official ruling and could not be legally binding. Since Mansfield discharged a slave on a writ of habeas corpus, many may have misinterpreted and associated his ruling with Henley's opinion, effectively making Henley's statement that, "As soon as a man sets foot on English ground, he is free" de-facto law in England. Historian Cotter outlines a slightly different approach, arguing that Somerset implied that slavery could not be supported in England unless specific legislation authorized slavery. ${ }^{12}$

Somerset was less about the status of slavery in England and more about the extension and jurisdiction of laws between the metropole and the colonial "periphery." Mansfield argued "So high an act of dominion must be recognized by the law where it is used. The power of masters over his slave has been extremely different, in different countries." ${ }^{13}$ Mansfield argued that the colonial laws that regulated slavery could not extend to England, including the rights of masters in other colonies, which could not be applied in England. Historian Rubin notes that laws enforced in England were limited by a myriad of colonial assemblies and statutes. Rubin further claims that, "The legal relationship between colony and metropole operated with a

\footnotetext{
11 "Shanley v Harvey (1762)," in Slavery, Abolition and Emancipation, ed. Micheal Craton, James Walvin and David Wright (London: Lowe \& Brydone Printers Limited, 1976): 168.

${ }^{12}$ Cotter, 32.

13 “Somerset v Stewart (1772)," 14-15.
} 
boundary drawn opportunistically depending on the circumstances." ${ }^{14}$ In other words, imperial law was a complex notion that mostly depended on the circumstances of the colony. While laws and statutes passed in colonial assemblies could not in any way breach jurisdiction and impact laws in England, there were circumstantial and "opportunistic" chances when the established practice of common law in England could affect colonies. Wiecek denies the proposed implications that Somerset influenced some colonies to directly challenge slavery. ${ }^{15}$ Nonetheless, there is evidence to suggest that English common law and the implications in Somerset directly affected the colony of Nova Scotia, a colony where no statute law regulated slavery. Indeed, Nova Scotia's judicial climate and confusion in regard to its own standing on slavery closely resembled that of England.

Nova Scotia's mass influx of enslaved people primarily resulted from loyalist migration to the colony. Prior to 1776, there were only a few white slave owners in Nova Scotia, yet after the American Revolution in 1783, there were nearly two thousand slaves in the colony. ${ }^{16}$ Whitefield argues that Nova Scotia's immigration of nearly 30,000 loyalists destabilized judicial and legislation institutions and facilitated a negotiation process for many black slaves to transition into the category of free black loyalist. ${ }^{17}$ In terms of tasks, slave labour compared considerably with the labour of English slaves in the sense that Nova Scotia did not have plantations or absentee owners. Instead, Nova Scotian slaves tended to work alongside their masters as multi-occupational slaves who served as servants or general labourers. ${ }^{18}$ Furthermore, as in England, it was reportedly hard to distinguish between a "slave" and "servant" in late

\footnotetext{
${ }^{14}$ Rabin, 19-20.

${ }^{15}$ Wiecek, 87.

${ }^{16}$ Whitefield, 37.

${ }^{17}$ Whitefield, 6.

${ }^{18}$ Whitefield, 49.
} 
eighteenth-century Nova Scotian society. Whitefield notes that during the loyalist migration, many British officials listed slaves as "servants" in order to deter potential American property claims in the future. ${ }^{19}$ Furthermore, historian Robin Winks believes that "slave" and "servant" were indiscriminately used in the Maritimes to refer to slavery. ${ }^{20}$ By the late eighteenth century, a minority of slave owners attempted to pass legislation in numerous ways to authorize slavery in Nova Scotia; nevertheless all attempts failed to pass. ${ }^{21}$ Therefore, Nova Scotia's ambiguous status of slavery closely mimicked the metropole.

In Nova Scotia no statute regulated slavery, therefore it was the role of judiciary officials to decide the fate of enslaved people. There is clear indication that the Chief Justices of Nova Scotia determined their rulings by proactively following the legal decisions in London regarding slavery. Writing in 1800, Chief Justice Blowers noted, "the judicial war of attrition against slavery in the province owed more to Knight v. Wedderburne than Somerset." ${ }^{\prime 22}$ In 1778, The Knight case appeared before the Scottish Supreme Court and was very similar to Somerset in that Knight escaped from his master, was captured, and planned to be sold abroad. The court ruled in Knight's favour and stated, "The Court were of opinion, that the dominion assumed over this negro, under the law of Jamaica, being unjust, could not be supported in this country to any extent $[\ldots]^{\prime 23}$ Perhaps what influenced Blowers to state that Knight was more influential than Somerset was the argument that the ruling in Knight was more direct in stating that slavery under English law was not tolerated nor legal in England, an element of directness that Somerset did not have. Furthermore, notes by Blower and his opinion on the legal status of slaves under

\footnotetext{
${ }^{19}$ Whitefield, 10.

${ }^{20}$ Robin Winks, The Blacks in Canada: A History, (Montreal: McGill-Queens University Press, 1997$), 45$.

${ }^{21}$ Whitefield, 63.

${ }^{22}$ Whitefield, 9.

23 “Knight v Wedderburn (1778)," in Slavery, Abolition and Emancipation, eds. Micheal Craton, James Walvin and David Wright (London: Lowe \& Brydone Printers Limited, 1976): 171.
} 
English common law influenced his decision that slavery without statute had no legal standing in Nova Scotia. Thus, legal arguments for the status of slavery in Nova Scotia did not come from local grievances or support. Instead they were influenced by London, an element that speaks to Nova Scotia's unique status as a colony in the transatlantic world. Nova Scotia had sympathetic judges, yet it was enslaved people themselves who displayed agency by running away and initiating legal proceedings. ${ }^{24}$ Historian and legal Scholar Barry Cahill notes that slaveholders failed to deter courts on upholding habeas corpus for slaves, thus habeas corpus was a direct way for slaves to secure their liberty through courts. ${ }^{25}$ Although Chief justice Blowers and his predecessor Thomas Strange were advocates of securing freedom for slaves, they were reluctant about ruling directly against the claims of slaveholders. Instead, they made it very difficult for slaveholders to prove that they legally owned an enslaved person presented in court. ${ }^{26}$ As Chief Justice Thomas Strange remarks, "wear out the Claim [of the owner] gradually than to throw so much property, as it is called, into the air at once." ${ }^{27}$ As the quote suggests, the Chief Justices were not concerned by their legal right to judge slavery as unlawful. The judges were concerned that slaveholders would file actions of trover (a claim to obtain damages for the misuse of property).

This comes to the fore in DeLancy v. Woodin (1800), perhaps the most famous case in Nova Scotia's slave legal history. A slave by the name of Jack, property of Colonel DeLancy, escaped his servitude and became employed by a Mr. Wooden. Upon hearing that Mr. Wooden employed Jack, DeLancy ordered Mr. Wooden to return his slave. Mr. Wooden refused on the

\footnotetext{
${ }^{24}$ Whitefield, 96.

${ }^{25}$ Barry Cahill, "Habeas corpus and Slavery in Nova Scotia: R. v. Hecht Ex Parte Rachel, 1798," University of New Brunswick Law Journal 44 (1995): 185.

${ }^{26}$ Whitefield, 101.

${ }^{27}$ Whitefield, 95.
} 
grounds that slavery did not exist in the colony of Nova Scotia. DeLancy (the plaintiff) then filled an action of trover against Mr. Wooden (the defendant) and received a retribution of seventy pounds. The defendant's counsel moved with an arrest of judgement (or motion that signals that the court has a lack of jurisdiction over the charge) upon the grounds that trover over Jack in the province of Nova Scotia had no legal standing. In 1804, DeLancy was poisoned and killed by one of his slaves and no official judgement was made. Nevertheless, Whitefield argues that DeLancy's failure to recover Jack as his slave demonstrated to slaveholders that the courts were not going to uphold slavery in the colony. ${ }^{28}$ Furthermore, DeLancy sought the legal advice of English chancellors regarding his claim for an action of trover over Jack in the colony of Nova Scotia.

This was later published in 1802 as Opinions of Several Gentleman of the Law, on the Subject of Negro Servitude, in the Province of Nova Scotia. In Opinions of Several Gentleman, Chancellor Aplin argues over the question of whether a black man or woman can be considered a slave (in terms of property) in Nova Scotia, and he states that, "such a question has never yet come directly before the Courts at Westminster-Hall." ${ }^{29}$ Aplin argues that he found one legal statute that acknowledged slavery in Nova Scotia under An Act for the regulating of Inn-Keepers. Therefore, the existence of slavery in a piece of legislation permitted DeLancy to use trover as a legal argument. ${ }^{30}$ In regards to Aplin's argument, evidence suggests that An Act for the regulating of Inn-Keepers was a piece of legislation passed by the New Brunswick assembly and not by the Nova Scotia assembly; therefore, no piece of legislation acknowledged nor authorized

\footnotetext{
${ }^{28}$ Whitefield, 102.

29 "Opinions of Several Gentleman of the Law, on the Subject of Negro Servitude, in the Province of Nova Scotia, 1802," The Internet Archive Library, https://archive.org/stream/cihm_95222\#page/n5/mode/2up (7).

30 "Opinions of Several Gentleman of the Law, on the Subject of Negro Servitude, in the Province of Nova Scotia, 1802," 8-9.
} 
slavery in the province of Nova Scotia, and Mr. Aplin's argument was not applicable. What is important to note is that while judges sought legal answers from England concerning the ambiguity of slavery in Nova Scotia, slaveholders were doing the same thing. Complicated legal questions arose such as whether or not England's laws could directly apply to a colony without statute law, or "the same law that makes them slaves there [West Indies], makes them slaves here [Nova Scotia], remains to be answered." 31

Nonetheless, by the late eighteenth and early nineteenth centuries, the courts had become so effective at ruling against slavery in Nova Scotia that some blacks living in Nova Scotia believed that stepping on Halifax soil would grant them automatic freedom. ${ }^{32}$ A false notion of automatic freedom was in some regard also shared by other colonies. On January 1st, 1795, thirty-one Maroons were captured during the Maroon Wars in Jamaica and were deported to Nova Scotia, "a country in which they would be free." ${ }^{33}$ Although the proclamation did not explicitly state that Nova Scotia was a colony without slavery, the statement clarified that their freedom would be secured and their chances of re-enslavement were unlikely.

Nova Scotia's legal system did not always provide freedom to enslaved people, and in some instances free black men and women faced dangers of kidnapping and re-enslavement. In 1787, Dick Hill was kidnapped and placed on a vessel headed for the West Indies to be sold in a slave market. Luckily, the courts accessed a certificate proving Hill`s freedom, and the vessel captain was forced to release him. ${ }^{34}$ John Clarkson, a black Loyalist who was key in organizing the Nova Scotian exodus to Sierra Leone in 1792, notes the story of Lydia Jackson. Following

\footnotetext{
31 "Opinions of Several Gentleman of the Law, on the Subject of Negro Servitude, in the Province of Nova Scotia, $1802, " 10$.

32 Whitefield, 92.

${ }^{33}$ Allister Hinds, "Deportees in Nova Scotia: the Jamaican Maroons," in Working Slavery, Pricing Freedom, ed. Verene A. Shepard (New York: Palgrave, 2001), 207.

${ }^{34}$ Whitefield, 13-14.
} 
the American Revolution, Jackson was tricked into signing an indenture that made her a servant for life. Jackson was then sold to Dr. Bulmer who brutally abused her. After finding out that Bulmer intended to sell Jackson in the West Indies, Jackson escaped to Halifax where it can be assumed that she migrated to Sierra Leone for permanent freedom. John Clarkson states, "I have so many others of a similar nature; for example, Scott's case, Mr. Lee, Senr. Case, Smith's child, Motley Roads child \& c." ${ }^{, 35}$ Clarkson's compilation of names demonstrates the chaotic realities concerning re-enslavement in Nova Scotia. Furthermore, they demonstrate individual experiences of black loyalists that are unfortunately lost to historians. Evidence suggests that reenslavement did not always signify transportation to the West Indies, and, in some cases, reenslavement was upheld in Nova Scotia. Mary Postell pleaded to the Shelburne Court of Appeals in 1786 and 1791 for the freedom of herself and her children on the grounds that she was unlawfully re-enslaved by Jesse Gray; unfortunately, her legal actions were unsuccessful. ${ }^{36}$ Furthermore, a witness by the name of Scipio testified on behalf of Mary Postell. As a result of his testimony, Scipio's house was set on fire, and one of his children was killed in the fire. ${ }^{37}$ This act of cruelty demonstrates the extent of "pressures" and pro-slavery tactics used by slaveholders. These tactics can also serve to explain why Chief Justices Bower and Strange were so reluctant to directly oppose slavery because of the potential retaliation of slaveholders against Nova Scotia's black population.

In conclusion, Somerset $v$ Stewart did not end slavery in England. Nevertheless, it did establish important legal principles regarding master and slave relations. Notably, a master could not remove a slave from England against their will, and a slave could gain a right to writ of

\footnotetext{
${ }^{35}$ Whitefield, 15.

${ }^{36}$ Carole W. Troxler, "Re-enslavement of Black Loyalists: Mary Postell in South Carolina, East Florida, and Nova Scotia," Journal of the History of the Atlantic 37, no. 2 (2008): 4.

37 Troxler, 8.
} 
habeas corpus. The Somerset ruling also implied that slavery could not be authorized, unless stated in statute law. More importantly, Somerset established imperial jurisdiction by stating that no colonial law could be maintained in England, yet established English law could be applied if warranted by the colonies. Nova Scotia, a colony with no statute law to regulate slavery, needed to be guided by the judicial rulings in England. Chief Justices Blowers and Strange were both influenced by the decisions in Somerset and Knight $v$ Wedderburne. Nonetheless, amid these influences, the Chief Justices did not rule directly against the institution of slavery. Instead they made it difficult for slaveholders to prove ownership of their slave. Nevertheless, judicial freedom was not always guaranteed, and many slaves remained in bondage for the rest of their lives. 


\section{Bibliography}

“Knight v Wedderburn (1778)." In Slavery, Abolition and Emancipation, edited by Micheal Craton, James Walvin and David Wright, 171. London: Lowe \& Brydone Printers Limited,

"Opinions of Several Gentleman of the Law, on the Subject of Negro Servitude, in the Province of Nova Scotia, 1802." The Internet Archive Library. https://archive.org/stream/cihm_95222\#page/n5/mode/2up.

"Shanley v Harvey (1762)." In Slavery, Abolition and Emancipation, edited by Micheal Craton, James Walvin and David Wright, 168. London: Lowe \& Brydone Printers Limited, 1976.

“Somerset v Stewart (1772)." In Judicial Cases Concerning American Slavery and the Negro. Edited by Helen Catterall, 14-15. Washington D.C: Carnegie Institute, 1926. 1976.

Cahill, Barry. "Habeas corpus and Slavery in Nova Scotia: R. v. Hecht Ex Parte Rachel, 1798." University of New Brunswick Law Journal 44 (1995): 170-210.

Cotter, William R. "The Somerset Case and the Abolition of Slavery in England." History 79, no. 255 , (1994): 31-56.

Hinds, Allister. "Deportees in Nova Scotia: the Jamaican Maroons." In Working Slavery, Pricing Freedom, edited by Verene A. Shepard, 206-222. New York: Palgrave, 2001.

Rabin, Dana. "“In a Country of Liberty?': Slavery, Villeinage and the Making of Whiteness in the Somerset Case (1772).” History Workshop Journal 72, (2011): 5-29.

Troxler, Carole W. "Re-enslavement of Black Loyalists: Mary Postell in South Carolina, East Florida, and Nova Scotia." Journal of the History of the Atlantic 37, no. 2 (2008): 1-13.

Whitefield, Harvey A. North to Bondage: Loyalist Slavery in the Maritimes. Vancouver: UBC Press, 2016.

Wiecek, William M. "Somerset: Lord Mansfield and the Legitimacy of Slavery in the AngloAmerican World.” The University of Chicago Law Review 42, no. 1 (1974): 86-146.

Winks, Robin. The Blacks in Canada: A History. Montreal: McGill-Queens University Press, 1997. 